\title{
The effect of the cutting edge helix angle of the cutter on the cutting force components and vibration acceleration amplitude
}

\author{
Wpływ kąta pochylenia krawędzi skrawającej frezu \\ na składowe siły skrawania i amplitudy przyspieszenia drgań
}

\section{JAN BUREK \\ ŁUKASZ ŻYŁKA \\ MARCIN PŁODZIEŃ \\ PAWE $\longleftarrow$ SUŁKOWICZ JAROSŁAW BUK *}

The influence of the cutting edge helix angle of the end milling cutter on the cutting force components and vibration acceleration amplitude in the workpiece coordinate system was determined during the high performance milling of aluminum alloy using the cutter with a wave shape of the cutting edge.

KEYWORDS: cutter, helix angle, aluminum, high performance milling

Aluminum alloys with unique properties such as low density, low resistance and good machinability (especially by material removal machining) have been used in aviation, aerospace and automotive industries. In the aerospace industry most commonly used aluminum alloy is $\mathrm{AlZn} 5.5 \mathrm{MgCu}$ wrought alloy. It can be found in the construction of aircraft carrier elements, such as: frames, ribs, spars and wings [1-3, 6].

Integral, homogeneous structural components are manufactured from a complete block of material by milling. Many times during the processing of this type of construction, more than $90 \%$ of the material is removed in the form of chips. Its characteristic feature is its thinwalled structure and large number of closed areas with relatively large depths [2, 4].

Due to the thin-walled structure of aluminum alloy integral structures and the large volume of material removed, the machining of these parts is carried out in a multi-stage manner. The first step - roughing and shaping - is performed by high performance cutting (HPC), which consists of removing the material in the shortest possible time by increasing the volume of removed material $Q_{w}$, i.e. radial infeed $a_{e}$, axial infeed $a_{p}$ and feedrate per tooth $f_{z}$ (fig. 1). The HPC machining, in addition to undeniable advantages, has some limitations, resulting, among others, from large sections of the cutting layer, which contributes to the formation of high cutting force component values. The most important are two components of the cutting force: normal to feed force $F_{\mathrm{fN}}$ and feed force $F_{\mathrm{f}}$, which influence on the stability of the milling process and act on the workpiece (fig. 1) [4-8].

Due to the high values of the cutting forces, the elastic deformation of both the cutter and the thin wall of the workpiece may occur. Because of high structural depths in the aircraft, large overhangs are required which results in lower rigidity. In addition, the rigidity of the entire machine tool - tool - workpiece system is reduced by the thinness of the workpiece.

* Dr hab. inż. Jan Burek (jburek@prz.edu.pl), dr inż. Łukasz Żyłka (zylka@prz.edu.pl), dr inż. Marcin Płodzień (plodzien@prz.edu.pl), mgr inż. Paweł Sułkowicz (psulkowicz@prz.edu.pl), mgr inż. Jarosław Buk (jbuk@prz.edu.pl) - Katedra Technik Wytwarzania i Automatyzacji na Politechnice Rzeszowskiej
DOI: https://doi.org/10.17814/mechanik.2017.11.155

Large tool extents, thin workpiece walls, and high cutting force component values in HPC machining also increase the risk generating self-excited vibrations in the machine tool - tool - workpiece system.

It is therefore desirable to reduce cutting force components to ensure high milling performance $[3,6,8]$.

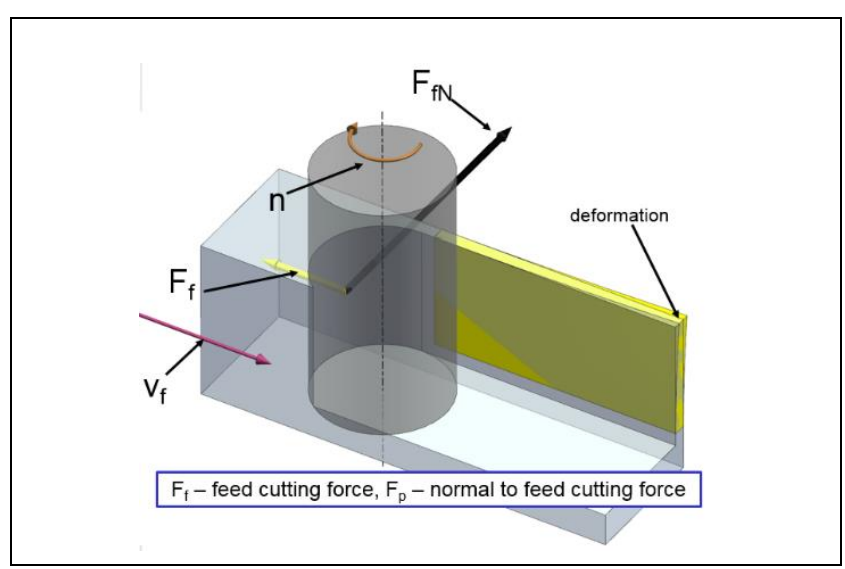

Fig. 1. Components of cutting force in HPC milling

One of the ways to reduce the cutting forces is to select geometric parameters of the tool (shape and helix angle of the cutting edge (fig. 2) [2-4]. For example, it has been shown that using a wavy or interrupted cutting edge profile contributes to a reduction in cutting force even by $30 \%$ as compared to continuous shape of the cutting edge [1, 2].

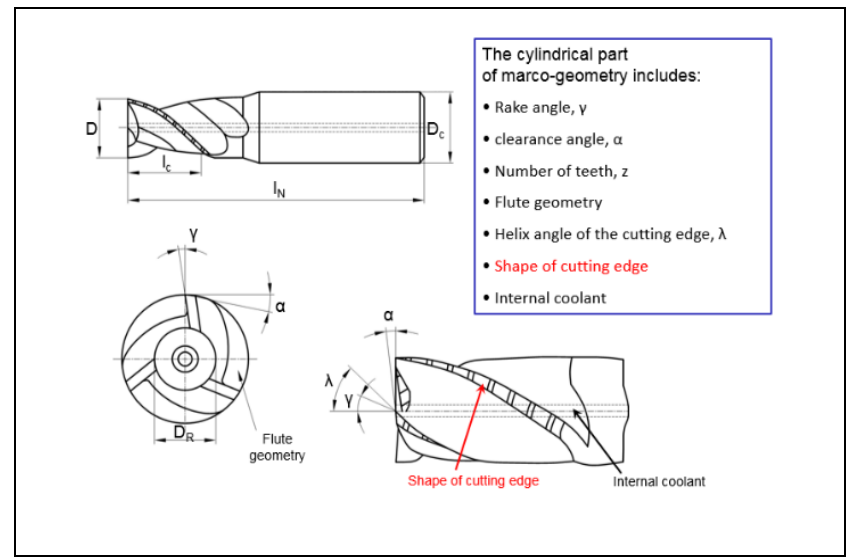

Fig. 2. HPC cutter

Another important parameter of the cutter geometry is helix angle of the cutting edge $\lambda$ (fig. 3). The influence of this angle on the values and distribution of cutting force components and the vibration acceleration amplitude during Alzn5.5MgCu aluminum alloy milling, is presented in this paper. 


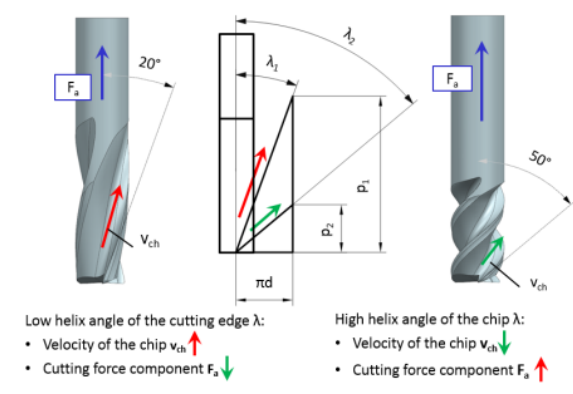

Fig. 3. Influence of the helix angle $\lambda$ of the cutting edge on the axia component $F_{\mathrm{a}}$ of the cutting force

\section{Test conditions}

High performance milling was performed on the DMG 100 monoBlock machining center (fig. 4).

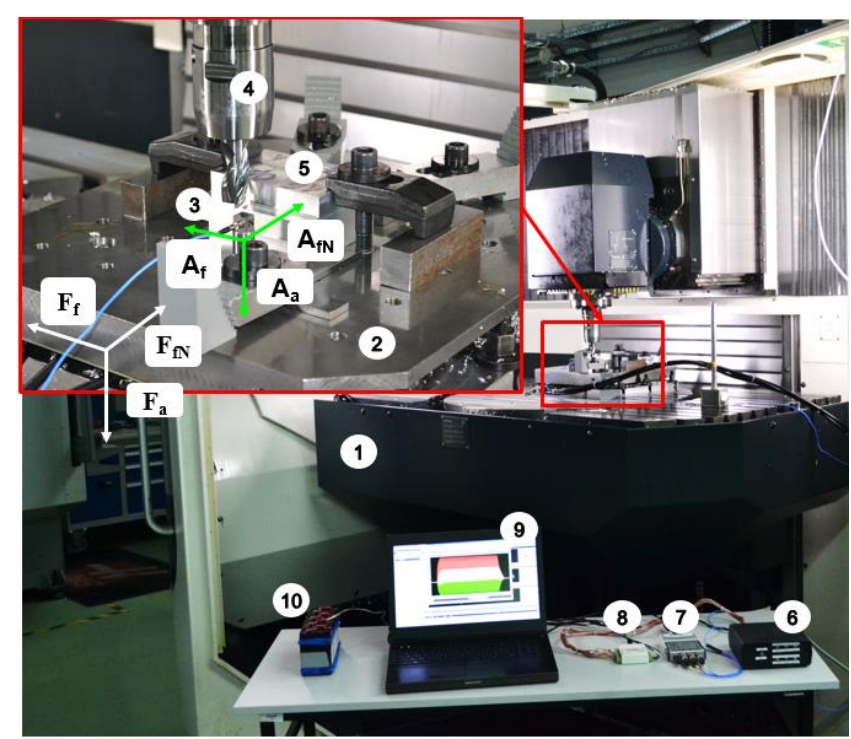

Fig. 4. Test stations: 1 - DMU 100 monoBlock milling center, 2 cutting force component platform, 3 - vibration amplitude sensor, 4 - tested cutter, 5 - test sample, 6- load amplifier control system, 7 - analog-to-digital converter for vibration sensor, 8 - analog-todigital converter for cutting force, 9 - computer with software, $10-$ external power supply for measuring platform

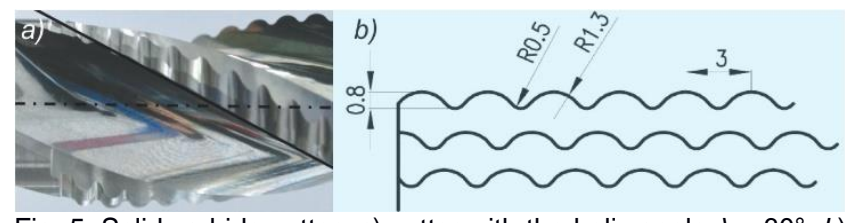

Fig. 5. Solid carbide cutter: a) cutter with the helix angle $\lambda=30^{\circ}, b$ ) shape of the cutting edge

Measurements of the cutting force components were recorded using a custom measuring platform consisting of 4 individual 3-element Kistler 9601A31 piezoelectric dynamometer. Measurement of vibration acceleration amplitude was done with 3-component PCB 356B21 vibration sensor. Monolithic solid carbide end mills with a diameter of $d=20 \mathrm{~mm}$ and an helix angle of the cutting edge in the range of $20^{\circ}$ to $50^{\circ}$ with $5^{\circ}$ increment (fig. 5a) were used. These cutters also featured a wavy shape of the cutting edge of the cutting edge (fig. 5b). The test samples were made of aluminum alloy $\mathrm{AIZn5.5MgCu}$ (7075).

The tests were performed with constant machining parameters: cutting speed $v_{\mathrm{c}}=694 \mathrm{~m} / \mathrm{min}$, axial infeed $a_{\mathrm{p}}$ $=15 \mathrm{~mm}$ and material removal rate $Q_{w}=594 \mathrm{~cm}^{3} / \mathrm{min}$. Material removal rate was obtained by selecting the pair of technological parameters of radial infeed $a_{\mathrm{e}}=8 ; 12 ; 16$ $\mathrm{mm}$ and feed per tooth respectively: $f_{\mathrm{z}}=0.15 ; 0.10$; $0.075 \mathrm{~mm} /$ tooth.

\section{Experimental results}

Results of the influence of the helix angle $\lambda$ of the cutting edge on the components of the cutting force and on the amplitude values of the vibrations are shown in fig. 6 and fig. 7 . Analyzing $F_{\mathrm{f}}$ and $F_{\mathrm{fN}}$ components of cutting force and comparing the results for maximum and minimum angle values $\lambda$, it can be seen that in combination with a helix angle $\lambda=20^{\circ}$ for $\lambda=50^{\circ}$ and:

- pair of machining parameters $a_{\mathrm{e}}=8 \mathrm{~mm}$ and $f_{z}=0.15$ $\mathrm{mm} /$ tooth of the cutting force component values decreased by: $F_{\mathrm{f}}$ by about $38 \%$ and $F_{\mathrm{p}}$ by about $40 \%$ (fig. $6 a)$;

- at $a_{\mathrm{e}}=12 \mathrm{~mm}$ and $f_{\mathrm{z}}=0.1 \mathrm{~mm} /$ tooth, $F_{\mathrm{f}}$ decreased by about $42 \%$ and $F_{\mathrm{p}}$ by about $32 \%$ (fig. $6 b$ );

- at $a_{\mathrm{e}}=16 \mathrm{~mm}$ and $f_{\mathrm{z}}=0.075 \mathrm{~mm} /$ tooth, $F_{\mathrm{f}}$ decreased by about $60 \%$ and $F_{\mathrm{p}}$ by about $23 \%$ (fig. $6 c$ ).

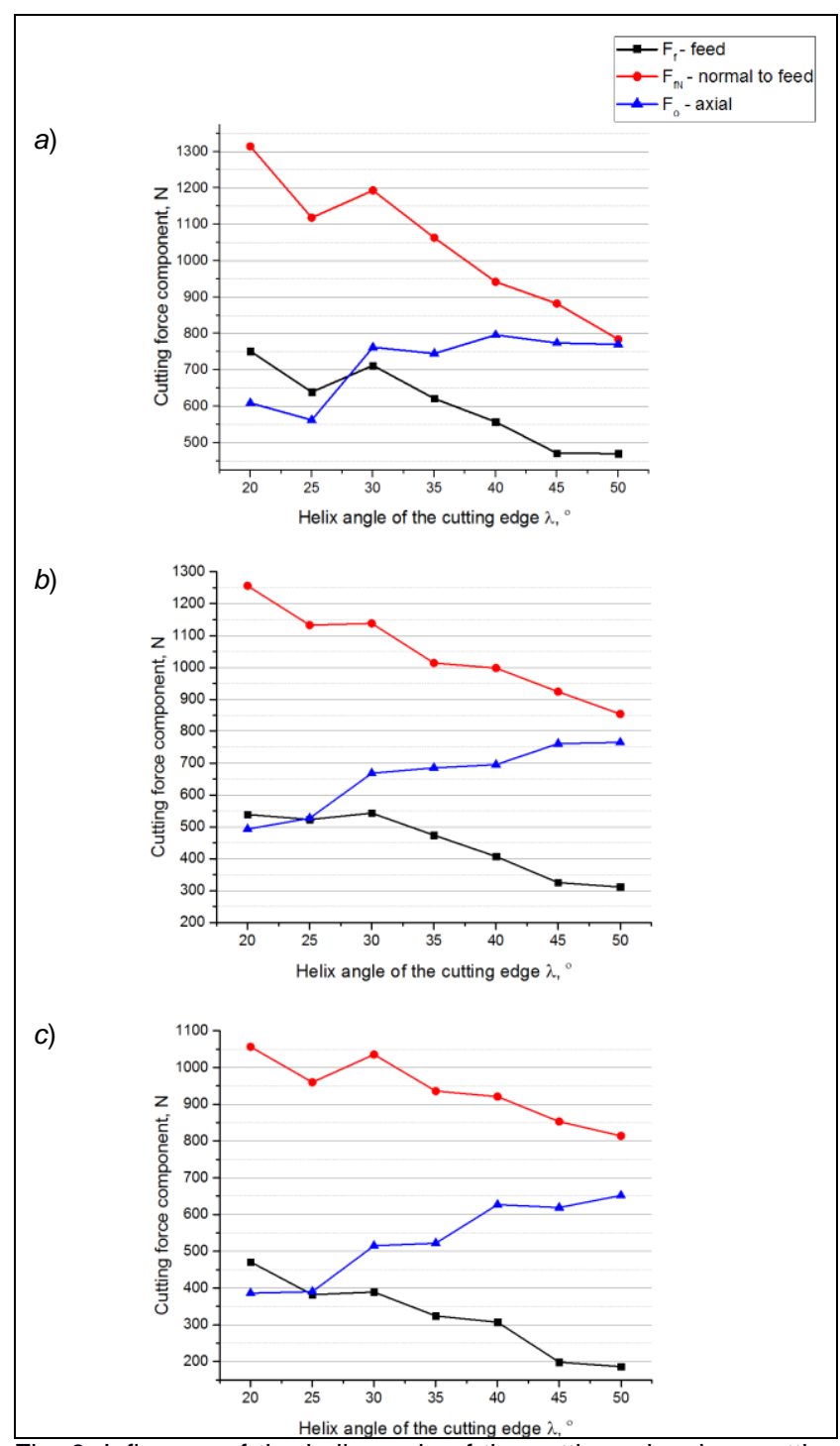

Fig. 6. Influence of the helix angle of the cutting edge $\lambda$ on cutting force components for machining parameters: a) $a_{\mathrm{e}}=8 \mathrm{~mm} ; f_{\mathrm{z}}=0.15$ $\mathrm{mm} /$ tooth, b) $a_{\mathrm{e}}=12 \mathrm{~mm} ; f_{\mathrm{z}}=0.10 \mathrm{~mm} /$ tooth, c) $a_{\mathrm{e}}=16 \mathrm{~mm} ; f_{\mathrm{z}}=$ $0.075 \mathrm{~mm} / \mathrm{tooth}$

Analysis of the results showed the monotonous nature of the characteristics of the cutting force components along with the change of helix angle $\lambda$ of the cutting edge. 
The increase in the angle of helix angle of the cutting edge causes the weakening of $F_{\mathrm{fN}}$ component and the feed force $F_{f}$ of the cutting force. The opposite situation was observed in the axial component $F_{\mathrm{a}}$ of cutting force, which in all trials increases with the increase of the angle $\lambda$.

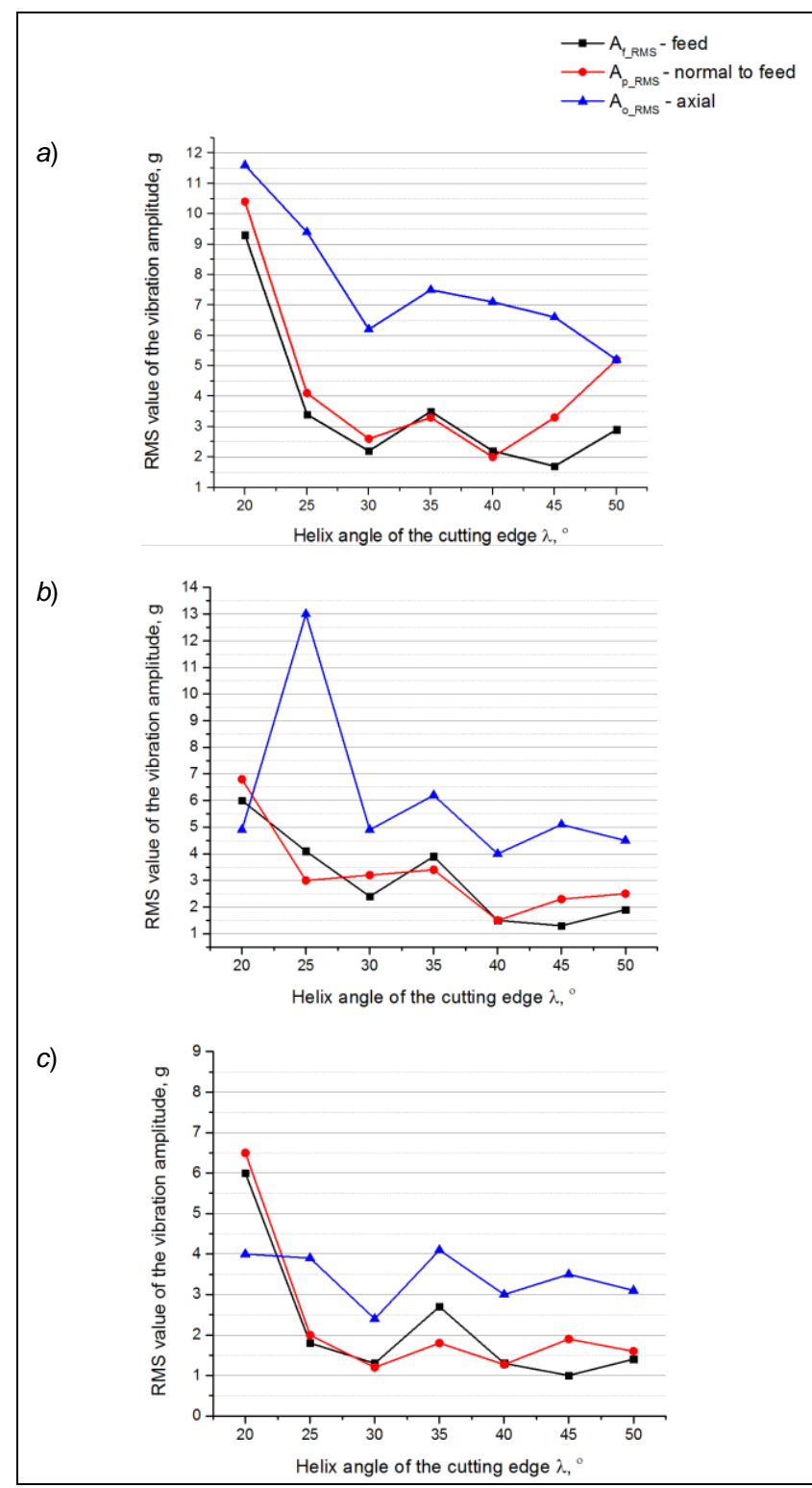

Fig. 7. Influence of the helix angle of the cutting edge $\lambda$ on the vibration amplitude values for the parameters: a) $a_{\mathrm{e}}=8 \mathrm{~mm} ; f_{\mathrm{z}}=0.15$ $\mathrm{mm} /$ tooth, b) $a_{\mathrm{e}}=12 \mathrm{~mm} ; f_{z}=0.10 \mathrm{~mm} /$ tooth, $c$ ) $a_{\mathrm{e}}=16 \mathrm{~mm} ; f_{\mathrm{z}}=$ $0.075 \mathrm{~mm} /$ tooth

On the other hand, in the case of the axial component $F_{0}$ of the cutting force for $\lambda=50^{\circ}$, an increase of its value was observed at approximately $26 \%$ (fig. $6 a$ ), $55 \%$ (fig. $6 b$ ) and $69 \%$ (fig. $6 \mathrm{c}$ ) in relation to the helix angle $\lambda=20^{\circ}$. In addition, based on the analysis of the pair of technological parameters, the lowest cutting force component values were obtained for the pair $a_{\mathrm{e}}=16 \mathrm{~mm}$ and $f_{z}=0.075 \mathrm{~mm} /$ tooth. These results show that, while maintaining constant machining efficiency, it is preferable to use larger radial feeds $a_{e}$ than feeds per tooth $f_{z}$ (fig. 6c).

The influence of the helix angle $\lambda$ on the values of the amplitude of the vibration acceleration shows the nonmonotonic nature of the changes in the amplitude of the vibration acceleration along with the change of this angle (fig. 7). Changes in the feed component $A_{\mathrm{f}}$ and the normal to feed component $A_{\mathrm{fN}}$ of the amplitude of the vibration acceleration, proceed in a similar manner and have the same effective amplitude values. The axial component is dominant and has the highest values relative to the other components.

The highest values of the vibrational acceleration amplitude components were recorded for the helix angle $\lambda=20^{\circ}$. The average effective value of the feed component $A_{\mathrm{f}}$ was about $8 \mathrm{~g}$, the normal to feed component $A_{\mathrm{AfN}}-$ about $9 \mathrm{~g}$, and the axial component $A_{\mathrm{a}}$ - about $6 \mathrm{~g}$. Increasing the angle $\lambda$ of the cutting edge tends to favor changes in the amplitude components of the vibration acceleration. It can be seen that the increase in the angle $\lambda$ results in a decrease in the feed component $A_{\mathrm{f}}$ and the normal to feed $A_{\mathrm{fN}}$ in the amplitude, which was also noticeable in the case of corresponding components of the cutting force. The reverse situation was observed in the axial component $A_{\mathrm{a}}$. As the angle $\lambda$ increases, the value of the axial component $A_{a}$ decreases due to the amplitude of the vibration, although at the same time, the increase of the axial component $F_{\mathrm{a}}$ of the cutting force has been observed. This is especially evident in the helix angle $\lambda>35^{\circ}$. This results in an increase in the natural frequency of machine tool - tool - workpiece system as a result of the load, thus stabilizing the milling process.

As with the cutting force component, the lowest vibrational amplitude component values were obtained for $a_{\mathrm{e}}=16 \mathrm{~mm}$ and $f_{\mathrm{z}}=0.075 \mathrm{~mm} /$ tooth. The results confirm that the use of larger radial $a_{\mathrm{e}}$ feeds than the feeds per tooth $f_{z}$ contributes to a more stable milling operation (fig. 7c).

\section{Conclusions}

On the basis of the research, it was found that the use of cutting edge helix angles in the range of $\lambda=40 \div 50^{\circ}$ results in a decrease in the feed component and the normal to feed component of about $30 \%$ on average, which is significant during the machining of HPC products with reduced rigidity. In addition, the use of such helix angles favorably reduces the amplitude of vibration, on average at about $3 \div 5 \mathrm{~g}$. However, it is important to note that for such large helix angles of the cutting edge, appropriate tool-mounting systems are required to provide sufficient clamping force to prevent the tool from slipping out due to the high axial component of the cutting force. It should be also remembered not to exceed the permissible axial force in the spindle of the machine tool.

\section{REFERENCES}

1. Burek J., Żyłka Ł., Płodzień M., Buk J. „Wpływ zarysu ostrza frezu na kształtowanie wiórów $\mathrm{w}$ wysokowydajnym frezowaniu stopu aluminium". Mechanik. 8-9 (2016) pages 1216-1217.

2. Burek J., Żyłka Ł., Gdula M., Płodzień M. „Wpływ zarysu linii ostrza frezu na siłę skrawania w procesie wysokowydajnej obróbki stopu AlZn5.5MgCu". Mechanik. 8-9 (2015): pages 275-284.

3. Kuczmaszewski J., Zaleski K. "Obróbka skrawaniem stopów aluminium i magnezu". Lublin: OWPL, 2015.

4. Burek J., Płodzień M. „Wysoko wydajna obróbka części ze stopów aluminium o złożonych kształtach”. Mechanik. 7 (2012): pages 542-549.

5. Kawalec A., Oczoś K.E. „Kształtowanie metali lekkich”. Warszawa: PWN, 2012.

6. Izamshah R., Yuhazri M.Y., Hadzley M., Amran M. "Effects of end mill helix angle on accuracy for machining thin-rib aerospace component". Applied Mechanics and Materials. 315 (2013): pages 773-778.

7. Oczoś K.E. „Obróbka wysokowydajna - HPC”. Mechanik. 11 (2004): pages 701-709.

8. Delio T. "Putting the High in Machining Performance". Tooling and Production. 68, 7 (2002): pages 38-41. 